\title{
Microbiological Quality of Surface Water Treated with Moringa oleifera Seeds or Cakes during the Storage: Case Study of Water Reservoirs of Loumbila, Ziga and Ouaga 3 Dams in Burkina Faso
}

\author{
Aminata Kabore ${ }^{1 *}$, Boubacar Savadogo², Harmonie C. Otoidobiga', Adama Sawadogo', \\ Francis Rosillon ${ }^{3}$, Alfred S. Traore1, Dayéri Dianou ${ }^{2}$ \\ ${ }^{1}$ Research Center for Biological, Alimentary and Nutritional Sciences, Research and Training Unit, Life and Earth \\ Sciences, University of Ouagadougou, Ouagadougou, Burkina Faso \\ ${ }^{2}$ Institute for Health Sciences Research, Ouagadougou, Burkina Faso \\ ${ }^{3}$ Water, Environment, Development Unit, Arlon Campus, University of Liège, Arlon, Belgique \\ Email: ${ }^{*}$ kab.amina@yahoo.fr
}

Received 18 February 2015; accepted 9 March 2015; published 10 March 2015

Copyright (C) 2015 by authors and Scientific Research Publishing Inc.

This work is licensed under the Creative Commons Attribution International License (CC BY). http://creativecommons.org/licenses/by/4.0/

(c) (i) Open Access

\begin{abstract}
Water purification with Moringa oleifera seeds has received a lot of attention because it reduces water turbidity and pathogenic microorganisms. However, it is important to define the optimum conditions of storage to preserve the treated water quality. The study aims to investigate microbial quality of water treated with Moringa oleifera seeds or cake coagulants in relation to the storage temperature and shelf life in order to define the optimum conditions of storage. A total of 45 water samples from 3 water reservoirs of Loumbila, Ziga and Ouaga 3 dams were collected in sterile glass bottles and treated in triplicate with Moringa oleifera seeds or defatted cakes coagulants. Treated water samples obtained at optimum conditions were stored at room temperature $\left(25^{\circ} \mathrm{C}-30^{\circ} \mathrm{C}\right)$ and at $4^{\circ} \mathrm{C}$. Fecal bacteria pollution indicators (Escherichia coli, fecal coliforms and fecal streptococcus) and parasites were monitored every 24 hours during three (3) days based on laboratory standard methods. Data were analyzed using the Student's t-test and XLSTAT 7.5.2 statistical software. From the results obtained, bacterial indicators increased significantly with storage temperature ( $p<$ $0.0001)$ and shelf life $(p<0.0001)$. However, for all water samples, bacterial growth was more important in samples treated with Moringa oleifera cakes than seeds $(p<0.0001)$. For water samples treated with Moringa oleifera seeds and stored at room temperature, bacterial increase after 72 hours was $57-80,42-50$ and $22-47 \mathrm{CFU} / 100 \mathrm{ml}$ for fecal coliforms, $E$. coli and fecal ${ }^{*}$ Corresponding author.
\end{abstract}

How to cite this paper: Kabore, A., et al. (2015) Microbiological Quality of Surface Water Treated with Moringa oleifera Seeds or Cakes during the Storage: Case Study of Water Reservoirs of Loumbila, Ziga and Ouaga 3 Dams in Burkina Faso. Journal of Water Resource and Protection, 7, 312-321. http://dx.doi.org/10.4236/jwarp.2015.74025 
streptococcus, respectively. With Moringa oleifera cake's treatment, the increase was 63 - 104, 57 82 and 28 - 52 for the same indicators, respectively. Bacterial growth was also more important at room temperature than at $4^{\circ} \mathrm{C}$. Thus, microbiological quality of water treated with Moringa oleifera seeds was better than cakes whatever storage temperature and shelf life. Overall, water treated with Moringa oleifera seeds should be stored at low temperature and consumed within 24 hours.

\title{
Keywords
}

\author{
Drinking Water, Moringa oleifera, Cake, Seed, Shelf Life, Microbiology
}

\section{Introduction}

Safe drinking water access for rural populations in developing countries remains a challenge for a sustainable development, particularly in Burkina Faso, where despite appreciable efforts undertaken to achieve the Millennium Development Goals (MDG), some rivers and well waters continue to be used in rural and periurban areas for human consumption [1]-[3]. Therefore, the household treatment of drinking water helps to reduce waterborne diseases which cause the death of 1.6 million children each year [4]. Because of commitments related to chemical treatment of drinking water at household, many studies have investigated the use of vegetable substances in water treatment. Thus, the effectiveness of Moringa oleifera seeds in drinking water purification has been shown in several studies [5]-[8]. However, the use of Moringa oleifera seeds in drinking water treatment showed some limits because of the increase of water organic matter in some cases [5] [9], which can lead to microbial proliferation during the storage [10]. Storage condition of drinking water is an important step in the preservation or degradation of water quality. In the present study, we examined the microbiological quality of water treated with Moringa oleifera seeds or cake coagulants with regard to storage temperature and shelf life in order to define the optimum conditions of storage.

After the presentation of the study zone and the methodology used, the results obtained will be presented. The quality of water will be discussed with regard to WHO standards and Moringa oleifera treatment [11].

\section{Study Zone}

Three (3) dams water reservoirs in the urban and periurban zones of Ouagadougou, namely Ouaga 3, Loumbila, and Ziga (Figure 1) were selected for the study. Loumbila and Ziga dams are located at 15 and $50 \mathrm{Km}$ of Ouagadougou, respectively while Ouaga 3 is within the city. These surface waters were used to supply drinking water to populations through treatment plants, for agriculture, recreational activities and in some cases as direct source of drinking water as well (Figure 2) [6] [12].

\section{Materials and Methods}

\subsection{Moringa oleifera Seeds and Defatted Cakes Coagulants Preparation}

The coagulants were prepared according to the methods described by Kakoré et al. and Folkard et al. [6] [9] [13]. Moringa oleifera seeds were obtained from the National Forest Seed Centre (NFSC). To obtain Moringa oleife$r a$ defatted cakes, the seeds were sorted and pressed with a press machine (ZX10) to remove about 30\% oil (Figure 3). The defatted cakes obtained were dried and crushed using the procedure described by Folkard et al. [13].

To prepare the Moringa oleifera seeds powder, the hulls and wings from the kernels were removed. The kernels were then crushed and ground to a medium fine powder according to Folkard et al. [13]. The coagulants from the cakes and seeds powders were then prepared following the procedure of Folkard et al. [13]. Appropriate quantities of Moringa oleifera seeds or cakes powder were placed into bottles that contained $500 \mathrm{ml}$ of sterilized distilled water, giving $20 \mathrm{~g} / \mathrm{l}$ and $100 \mathrm{~g} / \mathrm{l}$ concentrated stock solutions, respectively. The mixtures were stirred for one hour to extract the active protein of Moringa oleifera prior to water samples treatment. 


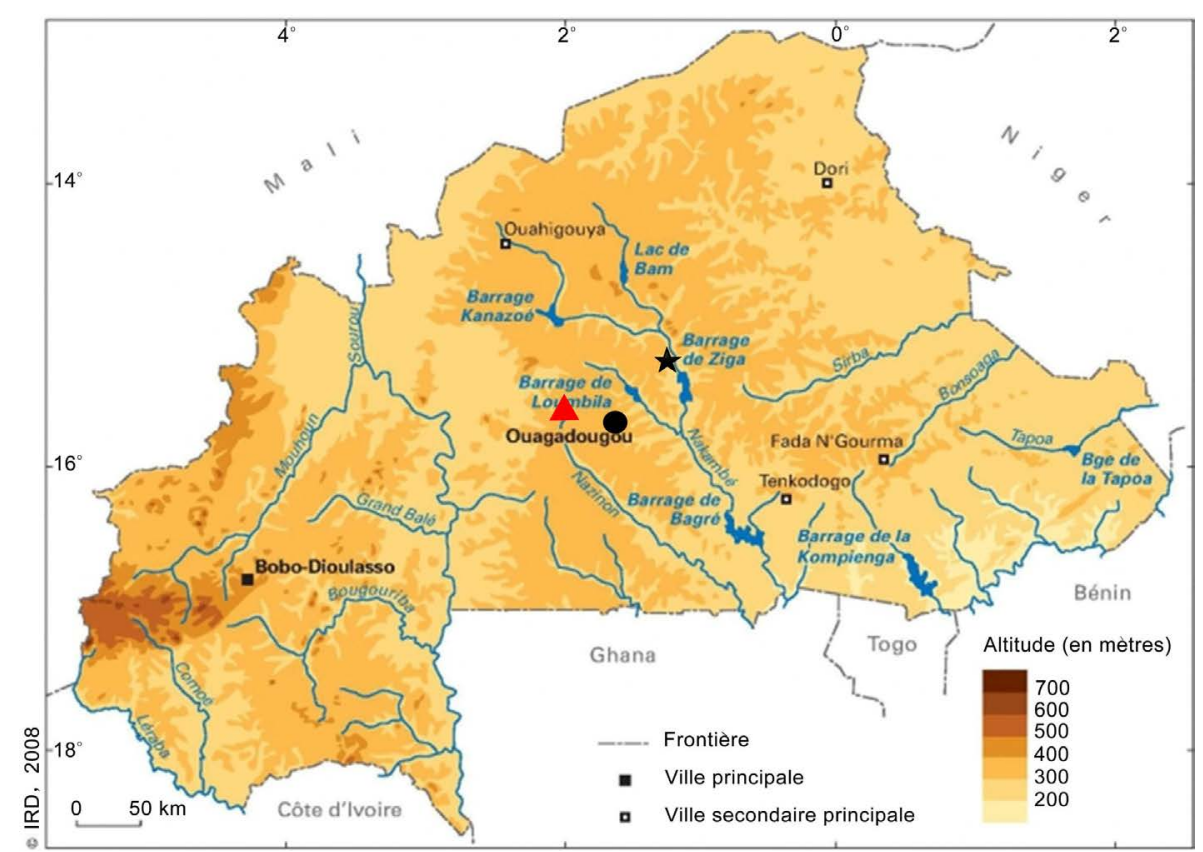

Figure 1. Location of the study zones (Dams of $\triangle$ Loumbila, $\star$ Ziga and Ouaga 3 ).

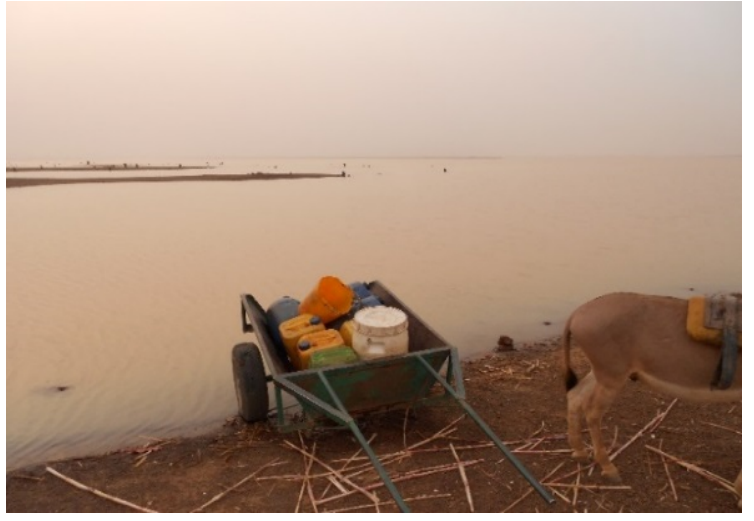

(a)



(b)

Figure 2. Drinking water sampling at the sites of Ziga (a) and Loumbila (b) during the study period (Kaboré et al. [6] [9]).

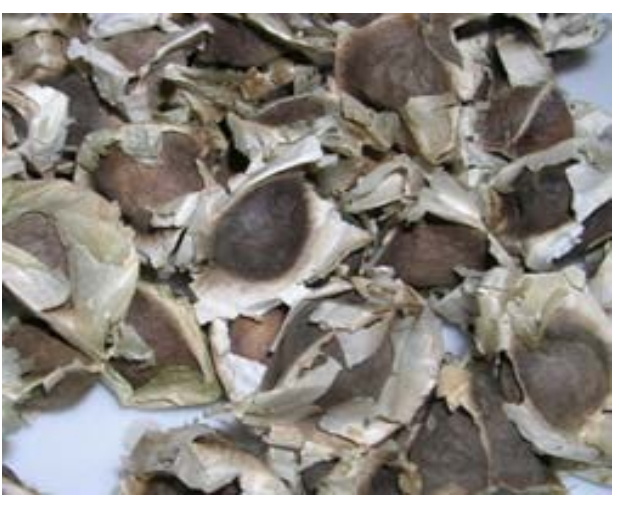

(a)

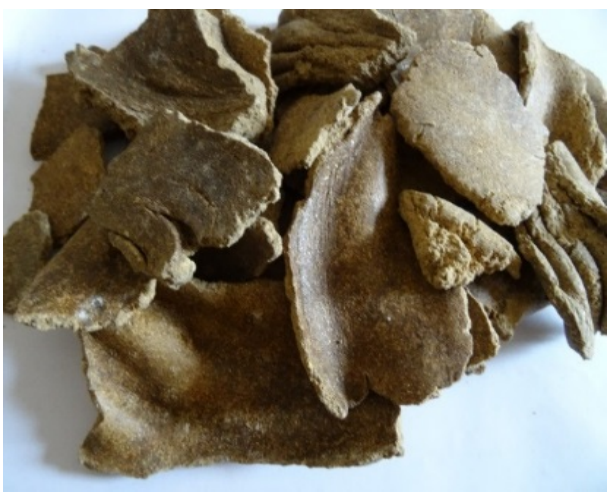

(b)

Figure 3. Moringa oleifera seeds (a) and cakes (b) (Kaboré et al. [6]). 


\subsection{Water Sampling}

Water samples were collected aseptically in triplicate into sterile glass bottles at the field. A total of 45 samples were collected at the field, preserved at $4{ }^{\circ} \mathrm{C}$ in cool boxes, carried to the laboratory and stored in a refrigerator at $4^{\circ} \mathrm{C}$ before treatment and analysis.

\subsection{Water Samples Treatment}

Water samples were treated in the laboratory in triplicate. Increased concentrations of Moringa oleifera seeds and defatted cakes coagulants were used to treat water samples according to Kakoré et al. [6] [9] in order to determine the appropriate concentrations for an optimum clarification of water samples. Experiments were carried out using the jar test (FC6S Velp Scientifica Jar-Test) (Figure 4). The test involved a rapid mixing, followed by a slow mixing then, sedimentation for $15 \mathrm{~min}, 30 \mathrm{~min}, 60 \mathrm{~min}$ and $120 \mathrm{~min}$, respectively. For each sedimentation period, $20 \mathrm{ml}$ of supernatant were taken for turbidity and $\mathrm{pH}$ measurements using a WTW 550 IR turbidity meter and a WTW 330i pH meter equipped with a Sen Tix 41 electrode, respectively in order to determine the optimal conditions and factors influencing the treatment. For each water sample, treatment that gave the lowest turbidity determined the optimum treatment conditions.

\subsection{Storage of Treated Water Samples}

Water samples treated with Moringa oleifera seeds or cakes coagulant at optimum processing conditions [6] [9], were stored into sterile glass bottles at room temperature $\left(25^{\circ} \mathrm{C}-30^{\circ} \mathrm{C}\right)$ and at $4^{\circ} \mathrm{C}$. Microbial parameters of the treated samples were monitoring every 24 hours during three (3) days.

\subsection{Microbiological Analysis of Water Samples}

Microbiological characteristics of water samples were determined before and after treatment at optimum processing condition in order to evaluate the treatment effect. Analyzes were performed at the National Office of Water and Sanitation and at the Institute for Health Sciences Research.

Three (3) bacterial indicators of fecal contamination namely Escherichia coli, fecal coliforms, fecal streptococcus were determined by the membrane filtration technique [14]. Bacterial cells were concentrated on a 0.2 $\mu \mathrm{m}$ Millipore Membrane Filter followed by culture on the chromogenic RAPID E. COLI 2 AGAR (BIO RAD) medium which contains 2 substrates specific to the $\beta$-D-Glucuronidase (Gluc) and $\beta$-D-Galactosidase (Gal) enzymes, respectively. Incubation was performed at $44.5^{\circ} \mathrm{C}$ for $24 \mathrm{~h}$. Colonies of $E$. coli (Gal+/Gluc + ) appear violet to pink while other coliforms colonies stain blue. On the Bile-Esculine-Azide medium, Gram positive cells able to reduce Esculine as fecal streptococcus stain black after $24 \mathrm{~h}$ incubation period at $37^{\circ} \mathrm{C}$, while Gram negative and other Gram positive cells are inhibited by sodium Azide.

Parasite eggs and/or cysts were identified and enumerated according to Ritchie [15] and consisted of a concentration of parasites with Formalin and Ether followed by a microscopic observation of the precipitate using lens 10 and 40 for the detection of parasite eggs or larva, and lens 100 with immersion oil after addition of two drops of a Iodine-Potassium iodide solution for the research of protozoa cysts.



Figure 4. Jar test for water sample clarification (Kaboré et al. [6]). 


\subsection{Statistical Analysis}

Data obtained were analyzed for water source and sampling period variations using the Student's t-test and XLSTAT 7.5.2 statistical software. Mean parameters concentrations were compared according to the Newman Keuls' test.

\section{Results and Discussion}

\subsection{Microbiological Parameters of Water Treated with Moringa oleifera Seeds and Cake Coagulants}

The microbiological parameters of water samples before and after treatment at optimum processing condition are presented in Table 1 and Figure 5. The Student's t-test (Table 1) revealed that the microbial characteristics of water samples were significantly related to the sampling site $(\mathrm{p}<0.0001)$ and M. oleifera treatment $(\mathrm{p}<0.0001)$. The joined effects of site and treatment affected also significantly $(p<0.0001)$ these characteristics.

For all water samples, mean concentrations of microbial pollution indicators (Figure 5) were significantly higher $(p<0.0001)$ in untreated water than in the treated one. Both treatments removed significantly concentrations of microbial pollution indicators (Figure 5). However, it appeared at optimum processing condition that Moringa oleifera seeds treatment is more efficient than Moringa oleifera cakes one (Figure 5). Globally, for all microbiological parameters, both treatments were more efficient for Ouaga 3 water samples as compared to Loumbila and Ziga ones, respectively $(\mathrm{p}<0.0001)$.

Table 1. Variance of microbiological parameters of water samples with regard to sampling site and Moringa oleifera treatment.

\begin{tabular}{|c|c|c|c|c|c|c|c|}
\hline \multirow{2}{*}{$\begin{array}{l}\text { Source of } \\
\text { variation }\end{array}$} & \multirow{2}{*}{ df } & \multicolumn{2}{|c|}{ Fecal coliforms $(\mathrm{CFU} / 100 \mathrm{ml})$} & \multicolumn{2}{|c|}{$\begin{array}{l}\text { Escherichia coli } \\
\text { (CFU/100 ml) }\end{array}$} & \multicolumn{2}{|c|}{$\begin{array}{l}\text { Fecal streptococcus } \\
\quad(\text { CFU/100 ml })\end{array}$} \\
\hline & & MS & $\mathrm{P}$ & MS & $\mathrm{P}$ & MS & $\mathrm{P}$ \\
\hline Site & 2 & 1581.48 & $0.002^{* *}$ & 381.481 & $<0.002^{* *}$ & 145.815 & $<0.018^{* *}$ \\
\hline Treatment & 2 & 25070.37 & $<0.0001^{* *}$ & 7359.26 & $<0.0001^{* *}$ & 1014.71 & $<0.0001^{* *}$ \\
\hline Site $x$ treatment & 4 & 737.037 & $<0.012^{* *}$ & 187.037 & $0.014^{* *}$ & 87.926 & $<0.043^{*}$ \\
\hline
\end{tabular}

MS: mean square; ${ }^{* *}$ significant $\mathrm{p}<0.01 ;{ }^{*}$ significant $\mathrm{p}<0.05$.

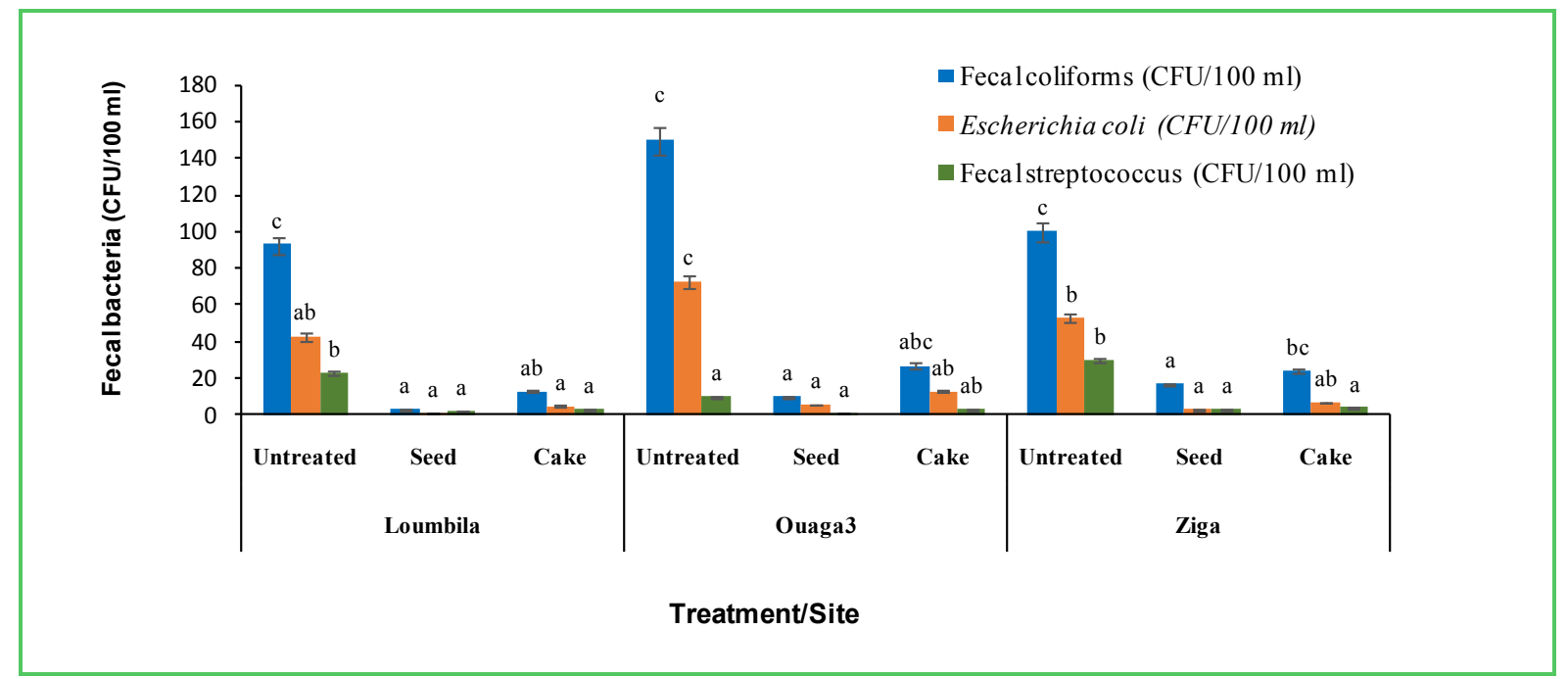

Figure 5. Mean concentration of fecal coliforms, E. coli and fecal streptococcus in water of Loumbila, Ouaga 3 and Ziga, treated or not with Moringa oleifera seeds and cake coagulants at optimal processing conditions. For a bacterial indicator, data sharing a same letter are not significantly different according to Newman Keuls's test at $\mathrm{p}<0.05$. 
These results confirm in some cases those obtained in our previous studies [6] [9]. However, the abatements recorded were lower than those of previous studies [6] [9]. The difference observed may be probably related to the initial characteristics of water samples and the sampling period as well [1] [6] [9]. Indeed, physicochemical and microbiological initial parameters of water samples affect the processing condition and the effectiveness of Moringa oleifera coagulants [6] [9] [16] [17].

Our previous results in agreement with those obtained by Fatombi et al. [5] [6] showed that depending on the characteristics of untreated water and treatment conditions, the purification of water with Moringa oleifera seeds causes an increase of organic matter content [5] [6]. According to Lautenschlager et al. [18], the abundance of bacteria in the water depends on the amount of nutrients in the form of organic carbon (sugar, amino acids, organic acids, etc.). Thus, drinking water should contain between 0.5 to $2 \mathrm{mg} / \mathrm{l}$ of dissolved organic carbon to ensure its microbiological stability [18]. To evaluate the microbial quality of water treated with Moringa oleifera seeds or cakes coagulants during the storage, fecal bacteria indicators were determined at different storage temperature and shelf life in order to define the optimum storage condition in household.

\subsection{Microbiological Quality of Water Treated with Moringa oleifera Seeds or Cakes in Relation to Storage Temperature and Shelf Life}

Table 2 presents the variance of microbial pollution indicators in water samples in relation to sample site, $M o$ ringa oleifera treatment, storage temperature and shelf life. The Student's t-test revealed that fecal coliforms, $E$. coli and fecal streptococcus were significantly related to the sampling site $(\mathrm{p}<0.0001)$, treatment $(\mathrm{p}<0.0001)$, storage temperature $(p<0.0001)$ and shelf life $(p<0.0001)$. The joined effects of shelf life and storage temperature affected also significantly $(\mathrm{p}<0.0001)$ these characteristics (Table 2$)$.

Globally, for all water samples, fecal coliforms, E. coli and fecal streptococcus increased during the storage and were related to shelf life and storage temperature $(\mathrm{p}<0.0001)$. Overall, for all water samples and Moringa oleifera treatment, statistical analysis showed that microbial pollution is proportional to shelf life. Thus, more the shelf life is longer, more microbial pollution was greater in treated water: 46,71 and $95 \mathrm{CFU} / 100 \mathrm{ml}$, for 24 , 48 and 72 hours, respectively. Concerning the storage temperature, statistical analysis showed that for all water samples, microbial growth was more significant $(\mathrm{p}<0.0001)$ at room temperature $(82 \mathrm{CFU} / 100 \mathrm{ml})$ than at $4^{\circ} \mathrm{C}$

Table 2. Variance of microbial pollution indicators in water samples of Loumbila, Ouaga 3 and Ziga in relation to sampling site, Moringa oleifera treatment, storage temperature and shelf life.

\begin{tabular}{|c|c|c|c|c|c|c|c|}
\hline \multirow{2}{*}{ Source of variation } & \multirow{2}{*}{ df } & \multicolumn{2}{|c|}{$\begin{array}{l}\text { Fecal coliforms } \\
\text { (CFU/100 ml) }\end{array}$} & \multicolumn{2}{|c|}{$\begin{array}{l}\text { Escherichia coli } \\
\text { (CFU/100 ml) }\end{array}$} & \multicolumn{2}{|c|}{$\begin{array}{l}\text { Fecal streptococcus } \\
(\text { CFU/100 ml })\end{array}$} \\
\hline & & MS & $\mathrm{p}$ & MS & $\mathrm{p}$ & MS & $\mathrm{p}$ \\
\hline Site & 2 & 8567.36 & $<0.0001^{* *}$ & 1089.58 & $<0.0001^{* *}$ & 1748.687 & $<0.0001^{* *}$ \\
\hline Treatment & 1 & 35784.03 & $<0.0001^{* *}$ & 5256.25 & $<0.0001^{* *}$ & 309.174 & $0.000^{* *}$ \\
\hline shelf life & 3 & 33713.66 & $<0.0001^{* *}$ & 11030.32 & $<0.0001^{* *}$ & 3645.137 & $<0.0001^{* *}$ \\
\hline Storage temperature & 1 & 74256.25 & $<0.0001^{* *}$ & 19834.03 & $<0.0001^{* *}$ & 6737.674 & $<0.0001^{* *}$ \\
\hline Site $^{*}$ storage treatment & 2 & 3171.53 & $<0.0001^{* *}$ & 268.75 & $0.025^{*}$ & 162.424 & $0.001^{* *}$ \\
\hline Site ${ }^{*}$ shelf life & 6 & 1988.65 & $<0.0001^{* *}$ & 63.6 & $0.493^{\mathrm{ns}}$ & 301.289 & $<0.0001^{* *}$ \\
\hline Site $^{*}$ storage temperature & 2 & 3868.75 & $<0.0001^{* *}$ & 284.03 & $0.020^{*}$ & 1224.799 & $<0.0001^{* *}$ \\
\hline Treatment ${ }^{*}$ shelf life & 3 & 1391.43 & $0.000^{* *}$ & 635.88 & $<0.0001^{* *}$ & 111.525 & $0.003^{* *}$ \\
\hline Treatment ${ }^{*}$ storage temperature & 1 & 10167.36 & $<0.0001^{* *}$ & 1284.03 & $<0.0001$ & 33.062 & $0.223^{\mathrm{ns}}$ \\
\hline shelf life ${ }^{*}$ storage temperature & 3 & 13108.1 & $<0.0001^{* *}$ & 3939.58 & $<0.0001^{* *}$ & 1380.211 & $<0.0001^{* *}$ \\
\hline Site $^{*}$ treatment ${ }^{*}$ storage temperature & 2 & 3009.03 & $<0.0001^{* *}$ & 63.19 & $0.410^{\mathrm{ns}}$ & 122.646 & $0.005^{* *}$ \\
\hline Site $^{*}$ shelf life ${ }^{*}$ storage temperature & 6 & 767.8 & $0.001^{* *}$ & 72.92 & $0.405^{\mathrm{ns}}$ & 272.197 & $<0.0001^{* *}$ \\
\hline Treatment $^{*}$ shelf life ${ }^{*}$ storage temperature & 3 & 989.58 & $0.001^{* *}$ & 234.03 & $0.023^{*}$ & 7.896 & $0.783^{\mathrm{ns}}$ \\
\hline
\end{tabular}

MS: mean square; ${ }^{* *}$ significant $\mathrm{p}<0.01 ;{ }^{*}$ significant $\mathrm{p}<0.05$; ns: not significant. 
(36 CFU/100 ml).

For water samples of Loumbila treated with Moringa oleifera seeds coagulant and stored at room temperature $\left(25^{\circ} \mathrm{C}-30^{\circ} \mathrm{C}\right)$, fecal coliforms increased to 17,34 and $57 \mathrm{CFU} / 100 \mathrm{ml}$ during 24,48 and 72 hours, respectively. For these same shelf lives, the increases of $E$. coli were 6,22 and $50 \mathrm{CFU} / 100 \mathrm{ml}$, respectively and 8, 28 and 40 $\mathrm{CFU} / 100 \mathrm{ml}$ for fecal streptococcus, respectively (Figure 6). On the other side, for the same water samples treated with Moringa oleifera cakes and stored at the same conditions, fecal coliforms increased to 18, 67 and $104 \mathrm{CFU} /$ $100 \mathrm{ml}$, respectively. E. coli increase was 19,48 and $57 \mathrm{CFU} / 100 \mathrm{ml}$, respectively while fecal streptococcus increased to 14, 43 and $52 \mathrm{CFU} / 100 \mathrm{ml}$, respectively (Figure 6).

Concerning water samples of Ouaga 3 treated with Moringa oleifera seeds and stored at room temperature, fecal coliforms increased to 25,40 and $67 \mathrm{CFU} / 100 \mathrm{ml}$ during 24, 48 and 72 hours, respectively. For these water samples, E. coli increased to 11,27 and $46 \mathrm{CFU} / 100 \mathrm{ml}$, respectively and fecal streptococcus to 9,17 and 22 $\mathrm{CFU} / 100 \mathrm{ml}$, respectively (Figure 7). For the same water samples treated with Moringa oleifera cakes and stored at the same conditions, fecal coliforms increased to 25,50 and $63 \mathrm{CFU} / 100 \mathrm{ml}$, respectively. E. coli increases were 24, 43 and $60 \mathrm{CFU} / 100 \mathrm{ml}$, respectively while fecal streptococcus increased to 4,18 and $28 \mathrm{CFU} / 100 \mathrm{ml}$, respectively (Figure 7).

With water samples of Ziga treated with Moringa oleifera seeds coagulants and stored at room temperature, fecal coliforms increased to 23, 51 and $80 \mathrm{CFU} / 100 \mathrm{ml}$ during 24, 48, 72 hours, respectively. For the same shelf lives, the increases of $E$. coli were 14, 27 and $42 \mathrm{CFU} / 100 \mathrm{ml}$, respectively while fecal streptococcus increased to 10,31 and $47 \mathrm{CFU} / 100 \mathrm{ml}$, respectively (Figure 8). On the other side, for the same water samples treated with Moringa oleifera cakes and stored at the same conditions, fecal coliforms increased to 51, 86 and $103 \mathrm{CFU} /$ $100 \mathrm{ml}$, respectively. E. coli increases were 23,51 and $82 \mathrm{CFU} / 100 \mathrm{ml}$, respectively while fecal streptococcus increased to 8, 29 and $47 \mathrm{CFU} / 100 \mathrm{ml}$, respectively (Figure 8). No parasite was found in the treated and untreated water samples.

Globally, the storage at $4^{\circ} \mathrm{C}$ lowered microbial growth in treated water. Thus, the microbial pollution in treated water was significant only after 48 hours (Figures 6-8). Whatever storage temperature and Moringa oleifera

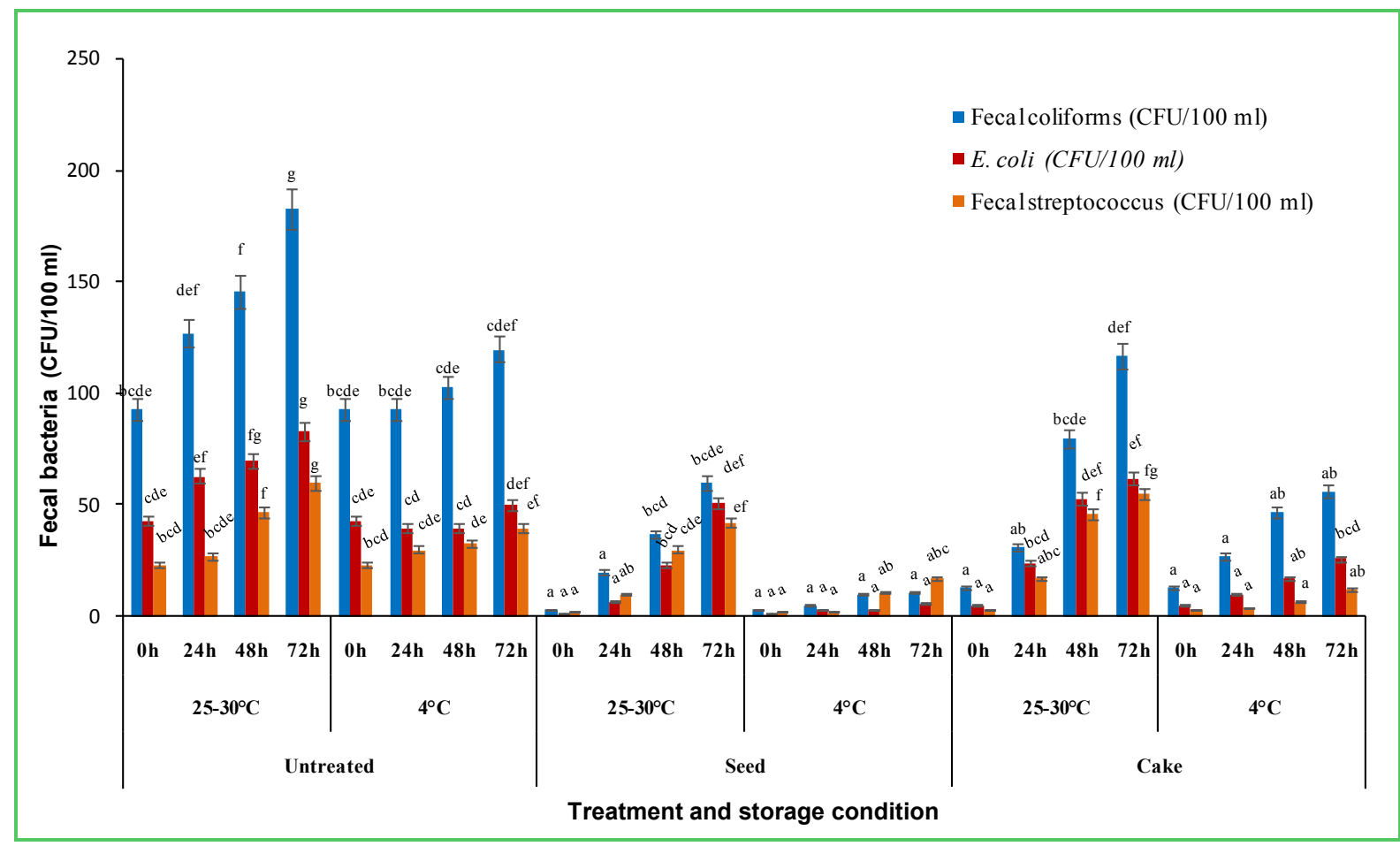

Figure 6. Mean concentration of E. coli, fecal coliforms and fecal streptococcus in water of Loumbila treated or not with Moringa oleifera seeds and cakes coagulants in relation to storage temperature $\left(4^{\circ} \mathrm{C}\right.$ or $\left.25^{\circ} \mathrm{C}-30^{\circ} \mathrm{C}\right)$ and shelf life $(0,24,48$ or 72 hours). For a bacterial indicator, data sharing a same letter are not significantly different according to Newman Keuls's test at $\mathrm{p}<0.05$. 


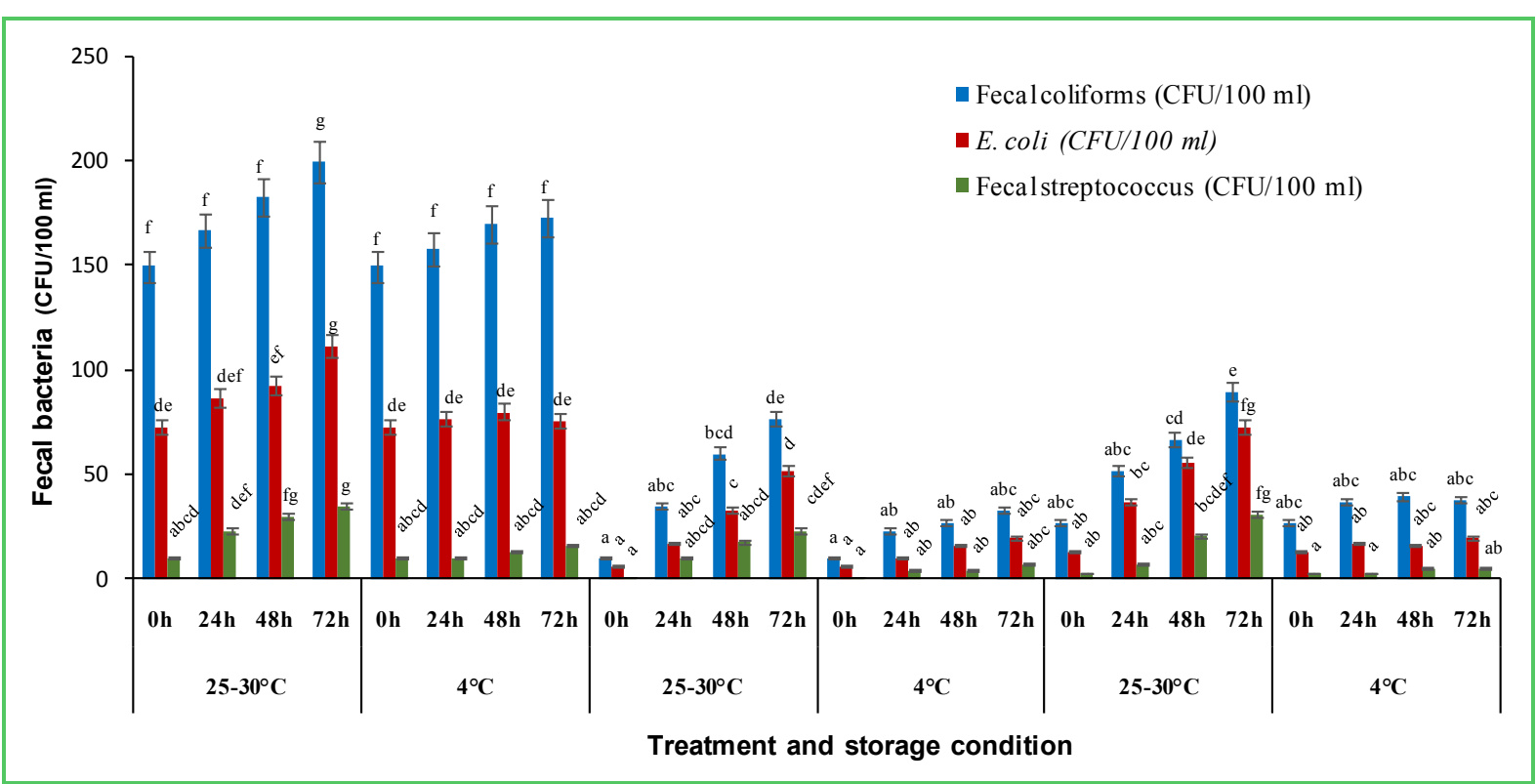

Figure 7. Mean concentration of $E$. coli, fecal coliforms and fecal streptococcus in water of Ouaga 3, treated or not with $M o$ ringa oleifera seeds and cakes coagulants in relation to storage temperature $\left(4^{\circ} \mathrm{C}\right.$ or $\left.25^{\circ} \mathrm{C}-30^{\circ} \mathrm{C}\right)$ and shelf life $(0,24,48$ or 72 hours). For a bacterial indicator, data sharing a same letter are not significantly different according to Newman Keuls's test at $\mathrm{p}<0.05$.



Figure 8. Mean concentration of E. coli, fecal coliforms and fecal streptococcus in water of Ziga, treated or not with Moringa oleifera seeds and cakes coagulants in relation to storage temperature $\left(4^{\circ} \mathrm{C}\right.$ or $\left.25^{\circ} \mathrm{C}-30^{\circ} \mathrm{C}\right)$ and shelf life $(0,24,48$ or 72 hours). For a bacterial indicator, data sharing a same letter are not significantly different according to Newman Keuls's test at $\mathrm{p}<0.05$.

treatment, it appears that the microbial quality of water degrades during the storage. However, the degradation is more important in water treated with Moringa oleifera cakes than with M. oleifera seeds. As reported some studies, this could be due to the presence of active antimicrobial agent in the seeds [19]. The active antimicrobial agent contained in the seeds could reduce bacterial growth in the treated water [19].

Thus, it appears that the storage of water treated with $M$. oleifera must consider the treatment type (M. oleife$r a$ seeds or cakes), the storage temperature and the shelf life. 


\section{Conclusion}

Unhygienic water causes waterborne diseases which have proven to be the biggest health threat worldwide and they contribute between $70 \%-80 \%$ of health problems in developing countries [20] [21]. Water treatment with Moringa oleifera seeds is an economical method that can purify drinking water in rural areas. However, the presence of organic matter in treated water promotes microbial recontamination during the storage. Thus, to preserve the microbiological quality, treated water should be stored at low temperature and consumed within 24 hours.

\section{Acknowledgements}

The authors would like to express profound gratitude to ISP-SUEDE/RABIOTECH, PACER-UEMOA/RABIOTECH, National Office of Water and Sanitation (ONEA), Institute for Health Sciences Research (IRSS) for financial and technical supports and to International Foundation for Sciences, Sweden (IFS), through a fellowship (W 5405-1).

\section{References}

[1] Dianou, D., Savadogo, B., Zongo, D., Zougouri, T., Poda, J.N., Bado, H. and Rosillon, F. (2011) Surface Waters Quality of the Sourou Valley: The Case of Mouhoun, Sourou, Debe and Gana Rivers in Burkina Faso. International Journal of Biological and Chemical Sciences, 5, 1571-1589.

[2] Koukounari, A., Gabrielli, A.F., Touré, S., Bosque-Oliva, E., Zhang, Y., Sellin, B., Donnelly, C.A., Fenwick, A. and Webster, J.P. (2007) Schistosoma haematobium Infection and Morbidity before and after Larges-Cale Administration of Praziquantel in Burkina Faso. Journal of Infectious Diseases, 196, 659-669. http://dx.doi.org/10.1086/520515

[3] Traoré, I. (2003) Impact of Geographical Factors on the Development of Schistosomiasis in the Sourou Valley. Master Thesis in Geography, University of Ouagadougou, Burkina Faso, 119 p.

[4] WHO (2005) The Effects of Environment on the Mother and Child Health. WHO, Geneva.

[5] Fatombi, K.J., Josse, R.G., Mama, D. and Aminou, T. (2009) Study of Flocculating Activity of Acid Casein Extracted from the Cream of Cocos nucifera in the Clarification of Surface Water. Journal of Water Sciences, 22, 93-101.

[6] Kaboré, A., Savadogo, B., Rosillon, F., Traoré, A.S. and Dianou, D. (2013) Effectiveness of Moringa oleifera Defatted Cake versus Seed in the Treatment of Unsafe Drinking Water: Case Study of Surface and Well Waters in Burkina Faso. Journal of Water Resource and Protection, 5, 1076-1086. http://www.scirp.org/journal/jwarp http://dx.doi.org/10.4236/jwarp.2013.511113

[7] Faby, J.A. and Eleli, A. (1993) Moringa Seed Use, Laboratory Jar-Test and Full-Scale. CIEH/EIER/Oieau, Urban Water and Sanitation Series, $132 \mathrm{p}$.

[8] Folkard, G.K., Sutherland, J.P. and Grant, W.P. (1989) Optimization on the Use of Natural Coagulants for Water Purification. Technical Report N R4254, Department of Engineering, University of Leicester, Leicester.

[9] Kaboré, A., Savadogo, B., Rosillon, F., Traoré, A.S. and Dianou, D. (2013) Optimization of the Effectiveness of the Moringa oleifera Seeds in the Treatment of Drinking Water in Sub-Saharan Africa: Case Study of the Waters of Burkina Faso. Journal of Water Sciences, 26, 209-220.

[10] Jahn, S.A.A. (1988) Using Moringa oleifera Lam. Seeds as Coagulant in Developing Countries. Journal of the American Water Works Association, 6, 43-50.

[11] World Health Organization (2011) Guidelines for Drinking Water Quality. 4th Edition, WHO, Genève, $531 \mathrm{p}$.

[12] Some, K., Dembele, Y., Somé, L. and Rasolodimby, J.M. (2008) Pollution of Nakambé Water Basin: The Case of Loumbila and Mogtedo Tanks in Burkina Faso. South Science and Technology, 16, 14-22.

[13] Folkard, G. and Sutherland, J. (2002) Development of a Naturally Derived Coagulant for Water and Wastewater Treatment. Water Supplies, 2, 89-94.

[14] American Public Health Association, American Water Works Association and World Peace Choral Festival (1998) Standard Methods for the Examination of Water and Wastewater. 20th Edition, American Public Health Association, American Water Works Association and Water Pollution Control Federation, Washington DC.

[15] Ritchie, L.S. (1948) An Ether Sedimentation Technique for Routine Stool Examination. Bulletin of US Army, 8, 326.

[16] Jahn, S.A.A. (1986) Proper Use of African Natural Coagulants for Rural Water Supplies Research in the Sudan and a Guide to New Projects. GTZ Manual No. 191.

[17] Jahn, S.A.A. (1989) Different Parts of Natural Coagulants in Water Clarification, in Appropriate Technologies for Do- 
mestic Use and in Municipal Wastewater Treatment Plants. Proceedings of International Seminar on the Use of Natural Coagulants for Water Treatment, Yogyakarta, 2-7 October 1989, 1-11.

[18] Lautenschlager, K., Boon, N., Wang, Y., Egli, T. and Hammes, F. (2010) Overnight Stagnation of Drinking Water in Household Taps Induces Microbial Growth and Changes in Community Composition. Water Research, 17, 4868-4877. http://dx.doi.org/10.1016/j.watres.2010.07.032.

[19] Bichi, M.H. (2013) A Review of the Applications of Moringa oleifera Seeds Extract in Water Treatment. Civil and Environmental Research, 3, 1-9.

[20] World Health Organization (2008) Guidelines for Drinking Water Quality. 3rd Edition, WHO, Geneva.

[21] Bina, L.J., Prasai, T., Singh, A. and Yami, K.D. (2009) Assessment of Drinking Water Quality of Madhyapur-Thimi and Study of Antibiotic Sensitivity against Bacterial Isolates. Nepal Journal of Science and Technology, 10, 167-172. 